\title{
Biotransformation of keratin waste to amino acids and active peptides based on cell-free catalysis
}

Zheng Peng ${ }^{1,3}$, Xinzhe Mao ${ }^{1,3}$, Juan Zhang ${ }^{1,3^{*}}$ (D) Guocheng Du ${ }^{1,3}$ and Jian Chen ${ }^{1,2^{*}}$

\begin{abstract}
Background: Keratin is the primary constituent of the vertebrate epidermis and epidermal appendages, as well as the main waste product generated during poultry processing from feathers, hair, scales, nails, etc. Keratin is generally hard, stubborn and difficult to hydrolyze; however, it is also inexpensive and contains more than $85 \%$ protein. Currently, tens of millions of tons of keratin waste are produced each year worldwide; however, no effective methods for the recovery of keratin waste have been reported thus far, making such research urgent. Keratinase has been reported to be useful for keratin waste recovery; however, nearly all keratinases are unable to hydrolyze keratin after they are detached from living cell systems. This may be due to low keratinase activity and lack of synergistic factors.

Results: Herein, the keratinase gene from Bacillus licheniformis BBE11-1 was successfully expressed in Bacillus subtilis WB600, allowing for improved activity of the recombinant keratinase KerZ1 to $45.14 \mathrm{KU} / \mathrm{mL}$ via promoter substitution and screening of the ribosome-binding sites. Further, real-time control of temperature, $\mathrm{pH}$, dissolved oxygen, and feed strategy allowed the activity of KerZ1 to reach $426.60 \mathrm{KU} / \mathrm{mL}$ in a 15 - L fermenter, accounting for a 3552-fold increase compared to the wild-type keratinase $(120.1 \mathrm{U} / \mathrm{mL})$. Most importantly, we proposed a method based on the synergistic action of keratinase KerZ1 and sodium sulfite, to hydrolyze feathers into amino acids. In specific, $100 \mathrm{~g} / \mathrm{L}$ of feather waste can be successfully converted into $56.6 \%$ amino acids within $12 \mathrm{~h}$, while supporting the production of dozens of bioactive peptides.
\end{abstract}

Conclusions: The activity of recombinant keratinase can be greatly enhanced via transcription and translational regulation in Bacillus subtilis. The synergistic action of keratinase and sulfite can rapidly degrade feather waste and produce amino acids and polypeptides.

Keywords: Keratin waste, Keratinase, Enzymatic hydrolysis, Amino acids and peptides

\section{Background}

With the consumption of meat products, tens of millions of tons of keratin waste are produced each year worldwide, of which feather waste accounts for approximately 8.5 million tons $[1,2]$. Keratin is highly prevalent in animal coverings, including feathers, hair, scales, and

*Correspondence: zhangj@jiangnan.edu.cn; jchen@jiangnan.edu.cn 1 School of Biotechnology, Jiangnan University, 1800 Lihu Road, Wuxi 214122, China

Full list of author information is available at the end of the article nails $[3,4]$. Further, the crude protein content of keratin waste is more than $85 \%$, which is a very attractive protein reserve; however, recycling of this product poses problems that are similar to those in case of cellulose [5]. Keratin materials, divided into $\alpha$-keratin and $\beta$-keratin, contain a large number of disulfide bonds, hydrogen bonds, and hydrophobic interactions, which are difficult to decompose [6-8]. High temperature, microwaving, and chemical methods (strong acid or alkali) have been explored for the decomposition and recovery of feathers. However, the violent reaction process leads to a

c) The Author(s) 2020. This article is licensed under a Creative Commons Attribution 4.0 International License, which permits use, sharing, adaptation, distribution and reproduction in any medium or format, as long as you give appropriate credit to the original author(s) and the source, provide a link to the Creative Commons licence, and indicate if changes were made. The images or other third party material in this article are included in the article's Creative Commons licence, unless indicated otherwise in a credit line to the material. If material is not included in the article's Creative Commons licence and your intended use is not permitted by statutory regulation or exceeds the permitted use, you will need to obtain permission directly from the copyright holder. To view a copy of this licence, visit http://creativeco mmons.org/licenses/by/4.0/. The Creative Commons Public Domain Dedication waiver (http://creativecommons.org/publicdomain/ zero/1.0/) applies to the data made available in this article, unless otherwise stated in a credit line to the data. 
significant loss of essential amino acids in the product, as well as enormous energy consumption, which places a notable burden on the environment [9-11].

Hence, transformation of agro-industrial wastes into valuable products has emerged as a "green" concept in sustainable industry. The discovery of keratinase revealed the potential to reuse keratin materials through biotechnological methods [12]. Keratinase is a proteolytic enzyme that specifically degrades hard keratin and is widespread in fungi and bacteria, which can break down keratin materials, converting them into soluble proteins, peptides, and amino acids [13, 14]. Keratinase has a broad spectrum of substrates, indicating its advantage for applications in degrading keratin polymers [15]. In fact, KERQ7 has shown higher levels of hydrolysis and catalytic efficiency than Basozym ${ }^{\circledR}$ CS10, Korobon ${ }^{\circledR}$ SC5K, and Pyrase ${ }^{\circledR}$ 250MP, which currently account for the primary commercial proteases employed for bating [16]. Moreover, Bacillus subtilis NRC3 was reported to show higher keratinase activity under extreme conditions, such as high salinity and high temperature, completely degrading feathers within 24 h [17], while the recombinant Bacillus amyloliquefaciens showed enhanced feather degradation properties and shortened reaction time within $12 \mathrm{~h}$ [18]. However, these keratinases exhibit minimal effects after they become detached from the host bacteria, posing a major obstacle to the commercialization of keratinase.

Recently, enzyme-based resource sustainability and environmental protection processes have rapidly evolved along novel, cleaner routes in an effort to become more efficient, easy to use, and functionally focused $[19,20]$. In addition, the rapid development of enzyme immobilization and protein engineering has furthered the customization of new recyclable industrial biocatalysts [21]. Keratinase, specifically, has demonstrated great potential in catalyzing keratin hydrolysis, and is, therefore, considered to be an ideal biocatalyst for the conversion of keratin waste [15, 22, 23]. However, the current use of keratinase to hydrolyze feathers is plagued by low enzyme activity and reduced processing capacity; thus, the true practical application of keratinase is yet to be recognized [24, 25]. Different research groups have sought to improve the functionality of keratinase. For instance, Yang et al. recombinantly expressed keratinase KerK in Bacillus amyloliquefaciens K11. Following a 60-h fermentation process, the resulting extracellular activity reached $1500 \mathrm{U} / \mathrm{mL}$ [18]. Further, Su et al. employed a recombinant $B$. subtilis keratinase mutant $\mathrm{M} 7$ to obtain $3040 \mathrm{U} / \mathrm{mL}$ of extracellular keratinase by continuous fermentation for $32 \mathrm{~h}$ in a 15-L bioreactor [26]. To this end, we also constructed a recombinant Bacillus subtilis strain that can efficiently express keratinase and found that we were able to rapidly process large amounts of feathers with the highly active recombinant keratinase KerZ1, to obtain a considerable amount of free amino acids and active peptides. The process of hydrolyzing feathers with ultra-high activity keratinase is quick and simple to operate, and the product yield is much higher than that in case of acid or alkali treatment. Most importantly, we have truly realized the potential for recycling of keratin waste in this simple, rapid, and green approach, which is conducive to industrial scale-up production.

\section{Results \\ Optimize keratinase expression levels through promoter substitution}

In previous studies, analysis of keratin degradation by wild-type strains showed that the activity of keratinase is directly related to the degree of keratin degradation [12, 27]. However, the activity of keratinase secreted by wildtype strains is limited. To increase the activity of keratinase, we constructed a heterologous expression system for the keratinase gene (NCBI database accession number: JX504681) in Bacillus subtilis with clear genomic information. Four recombinant strains were constructed based on constitutive and inducible promoters. The recombinant strains, B. subtilis WB600-pMA5-ker and B. subtilis WB600-pP43NMK-ker, were fermented for $48 \mathrm{~h}$ at $37{ }^{\circ} \mathrm{C}$ and $220 \mathrm{rpm}$ in the initial medium. Figure 1a shows that significant differences were apparent in the expression of keratinase between the two constitutive promoters. The activity of extracellular keratinase expressed by Bacillus subtilis WB600-pMA5-ker was 2514.4 U/mL, while that of Bacillus subtilis WB600pP43NMK-ker reached $6659.0 \mathrm{U} / \mathrm{mL}$. Although the promoters $\mathrm{P}_{\text {HpaII }}$ and $\mathrm{P}_{43}$ carried by the pMA5 and pP43NMK plasmids, respectively, were both strong promoters and the copy number of the plasmids was high, P43 had a higher ability to initiate transcription than $\mathrm{P}_{\text {HpaII }}$, thus leading to a significant difference in protein expression $[28,29]$.

Successful expression of keratinase by the recombinants B. subtilis WB600-pSTOP1622-ker and B. subtilis WB600pHT43-ker was based on the induction of xylose and IPTG [30]. When the cell concentration of the fermentation system reached $0.8\left(\mathrm{OD}_{600}=0.8\right)$, xylose with a final concentration of $0.5 \%$ and IPTG with a final concentration of $0.4 \mathrm{mM}$ were added, followed by incubation at $37{ }^{\circ} \mathrm{C}$ and shaking conditions of $220 \mathrm{rpm}$ for $48 \mathrm{~h}$. The corresponding recombinant strains had an extracellular keratinase activity of $2296.4 \mathrm{U} / \mathrm{mL}$ and $1353.6 \mathrm{U} / \mathrm{mL}$, respectively (Additional file 1: Figure S1). Although the pHT43 plasmid contains the Theta replicon, the copy number of the plasmid is low $(\leq 10)$, and the recombinant protein is not readily expressed in large quantities [31]. Hence, $B$. subtilis 


\section{a}
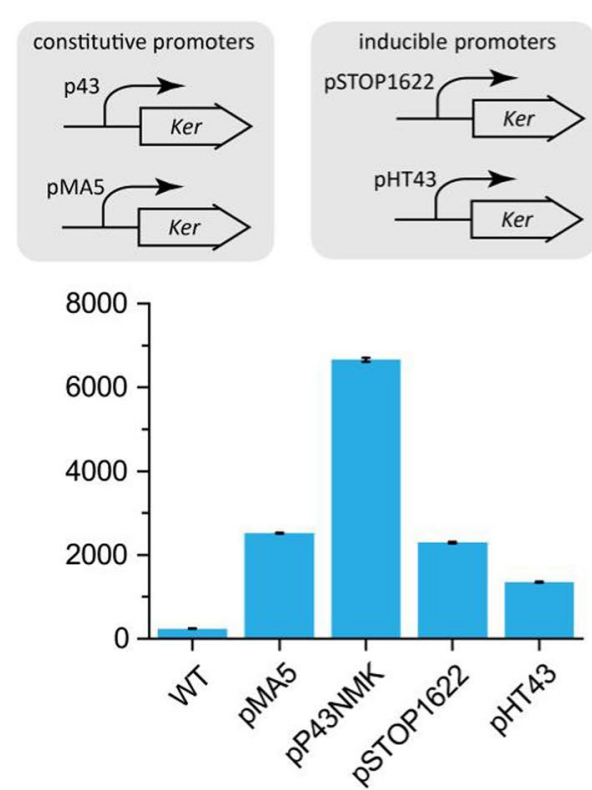

C

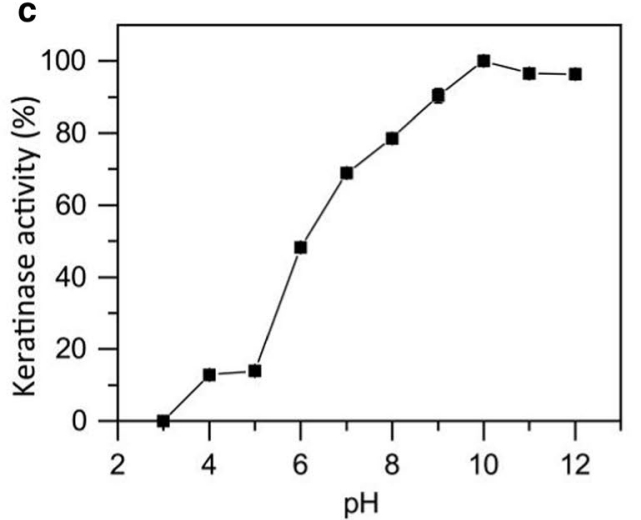

e

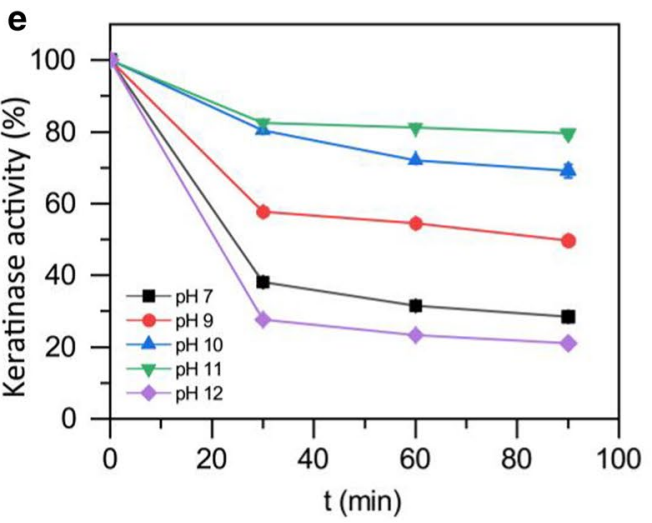

b

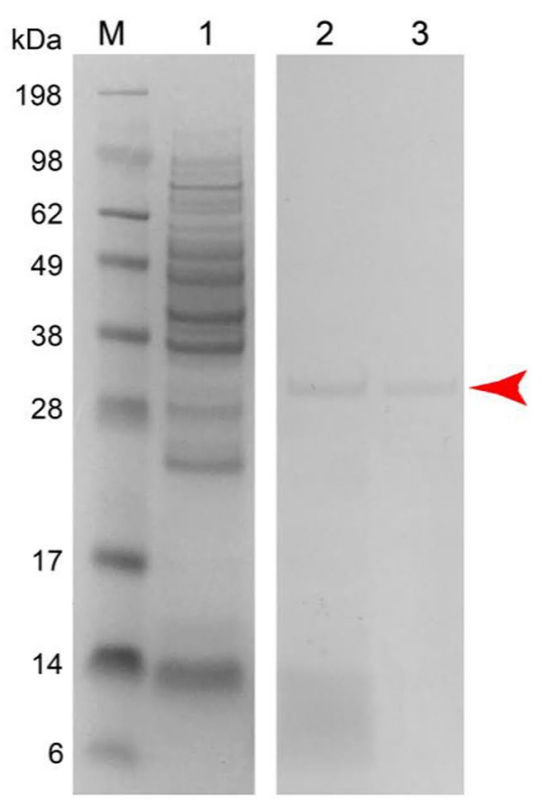

d

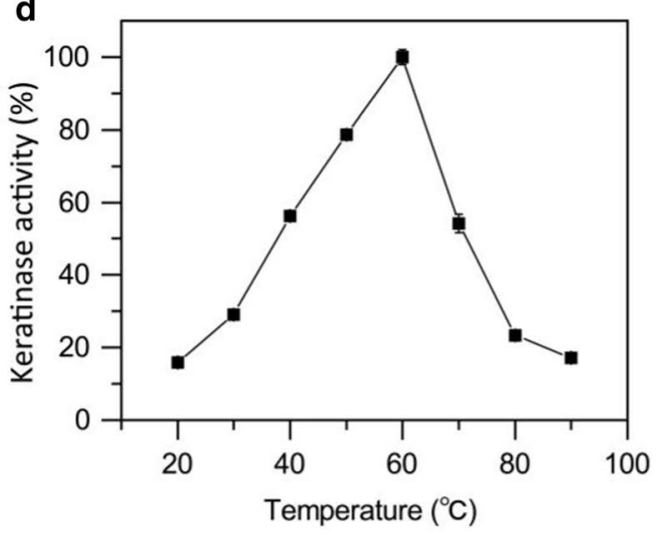

f

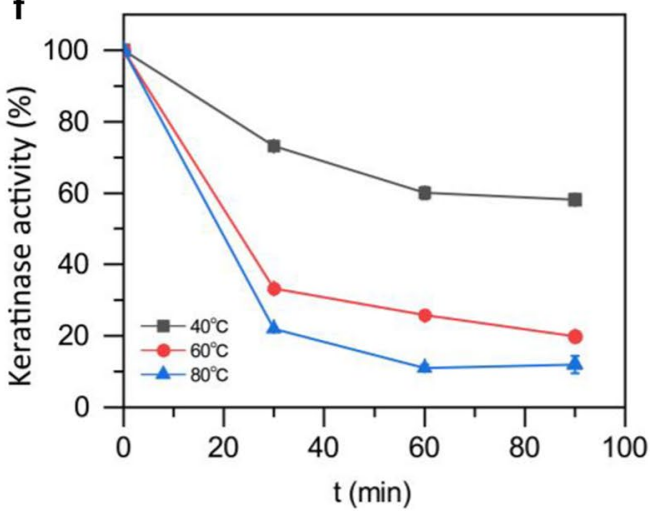

Fig. 1 Effect of promoters on keratinase activity and the enzymatic properties of recombinant keratinase KerZ1. a Schematic representation of different promoters and their corresponding keratinase activities. WT: wild-type keratinase activity secreted by Bacillus licheniformis BBE11-1. b SDS-PAGE analysis of recombinant keratinase. Lane 1: The fermentation supernatant of Bacillus subtilis WB600, Lane 2: Recombinant keratinase KerZ1, Lane 3: Purified recombinant keratinase KerZ1. c Optimum pH of KerZ1. d Optimum temperature of KerZ1. e pH stability. KerZ1 was appropriately diluted with buffers of different $\mathrm{pH}$ and incubated at $37^{\circ} \mathrm{C}$ for $90 \mathrm{~min}$, after which the residual enzyme activity of keratinase was measured at an interval of $30 \mathrm{~min}$. f Temperature stability. KerZ1 was incubated at different temperatures for 90 min. The residual enzyme activity of keratinase was then measured at an interval of $30 \mathrm{~min}$ 
WB600-pP43NMK-ker, which expresses keratinase activity prominently, was chosen for further research on keratinase.

\section{Purification and characterization of keratinase}

To facilitate the purification of recombinant keratinase KerZ1, a 6-His tag was added to the N-terminus of the mature enzyme and a recombinant strain was subsequently constructed. After $48 \mathrm{~h}$ of fermentation under the same conditions, the supernatant of the fermentation broth was examined by SDS-PAGE. It should be noted that with the exception of KerZ1, only a few non-target bands are concentrated in the low molecular weight region in the supernatant. However, in the supernatant of the B. subtilis WB600 fermentation broth containing no recombinant plasmid, there were numerous proteins with various molecular weights. These results indicate that keratinase has a broad spectrum of substrates; when KerZ1 is overexpressed, other proteins are decomposed by KerZ1 to form a protein or peptide with a smaller molecular weight [32]. Moreover, these results also demonstrate that KerZ1 has a strong capacity for degrading proteins, which is why it is widely applicable in various fields of scientific research and industries.

Based on the AKTA protein purification system (General electric, USA), KerZ1 was bound to a nickel column and eluted with $5 \%$ imidazole to obtain purified KerZ1, as presented in Fig. 1b. In addition, Fig. 1c, d shows the enzymatic properties of KerZ1, which demonstrated the highest keratinase activity at $\mathrm{pH} 10$ and $60{ }^{\circ} \mathrm{C}$. KerZ1 also exhibited excellent stability at $\mathrm{pH} 9-11$, especially at $\mathrm{pH} 10$ and 11 (Fig. 1e). Although KerZ1 has the most optimal activity at $60{ }^{\circ} \mathrm{C}$, it also demonstrates excellent stability at lower temperatures of $40^{\circ} \mathrm{C}$, which is advantageous for storage of KerZ1 (Fig. 1f).

\section{Rationally designed translation initiation sequence to improve keratinase expression}

Sodium dodecyl sulfate-polyacrylamide gel electrophoresis (SDS-PAGE; Fig. 1b) of recombinant keratinase KerZ1 demonstrated that the extracellular expression of keratinase was limited, which is detrimental to its large-scale production and application. The efficiency of translation initiation in bacterial cells is determined by the performance of the ribosome-binding site (RBS); while translation initiation affects translation efficiency by more than 100-fold [33], appropriate promoter and RBS sequences can greatly increase the expression level of the protein [34]. To increase keratinase expression, the RBS was rationally designed to improve translation efficiency via prediction of the keratinase translation level using the RBS Calculator v2.0 (https://salislab.net/software/forward) [35]. As the RBS sequence was moved closer to the translation region, its influence on translation initiation efficiency decreased [35] (Fig. 2a). Therefore, a library containing 4096 mutants was constructed via imposing a saturation mutation (GNNNNNNAGG) upstream of the keratinase gene sequence from the -13 to -18 region based on the original RBS sequence $5^{\prime}$-GTAAGAGAGG-3' in the p43NMK plasmid. We then selected 3 times the number of theoretical transformants to achieve 95\% coverage. Eleven mutants (Table 1) with a predicted $\Delta G_{\text {total }}$ between -10 and -15 were selected for further shake flask fermentation. The keratinase activity of the 11 mutants exceeded 15,000 U/ $\mathrm{mL}$, and the most superior mutant, RBS3, showed a keratinase activity of $45.14 \mathrm{KU} / \mathrm{mL}$ (Fig. 2b). SDS-PAGE analysis for keratinase expression revealed that the mutants RBS1, RBS2, RBS3, and RBS9 exhibited significant improvement relative to the original recombinant enzyme (Fig. 2c). The above results indicate that our strategy for improving the expression level of KerZ1 at the translational level was successful.

\section{Process optimization and scale-up in 15-L fermenter}

Previous studies have successfully expressed keratinase in B. subtilis WB600 and have greatly increased the level of enzyme activity; however, they remain unable to meet the growing needs of industrial production and commercialization. The use of larger reactors to further increase the production of keratinase and to test the stability of the fermentation process is, therefore, an important property to measure the industrialization capacity of the enzyme. The recombinant strain RBS3 was inoculated at a percentage of $5 \%(\mathrm{v} / \mathrm{v})$ in a $15-\mathrm{L}$ fermenter to produce keratinase using the optimized medium (Additional file 1: Figure S2). The fermentation was carried out by maintaining $\mathrm{pH}$ at 7.0 via automatic addition of phosphoric acid and ammonia, keeping the dissolved oxygen (DO) above $30 \%$ by controlling DO associating with agitation speed, and feeding glucose at a constant rate of $28.8 \mathrm{~g} / \mathrm{L} / \mathrm{h}$ within $6-18 \mathrm{~h}$ for high-density fermentation. As a result, the DCW of the culture broth was $29.13 \mathrm{~g} / \mathrm{L}$ following continuous fermentation for $28 \mathrm{~h}$, and the yield and productivity of KerZ1 reached 426.60

(See figure on next page.)

Fig. 2 Effects of ribosome binding on translation initiation rate and keratinase activity in the corresponding mutant. a Prediction of the keratinase translation level using the RBS Calculator v2.0 (https://salislab.net/software/forward). b Keratinase activity corresponding to RBS mutants. c Analysis of keratinase expression by SDS-PAGE. Lane 1: RBS1, Lane 2: RBS2, Lane 3: RBS3, Lane 4: RBS9, Lane 5: Keratinase expressed by a recombinant strain containing the original RBS sequence served as a control (CK). d Batch fermentation of mutant RBS3 in $15 \mathrm{~L}$ fermenter 


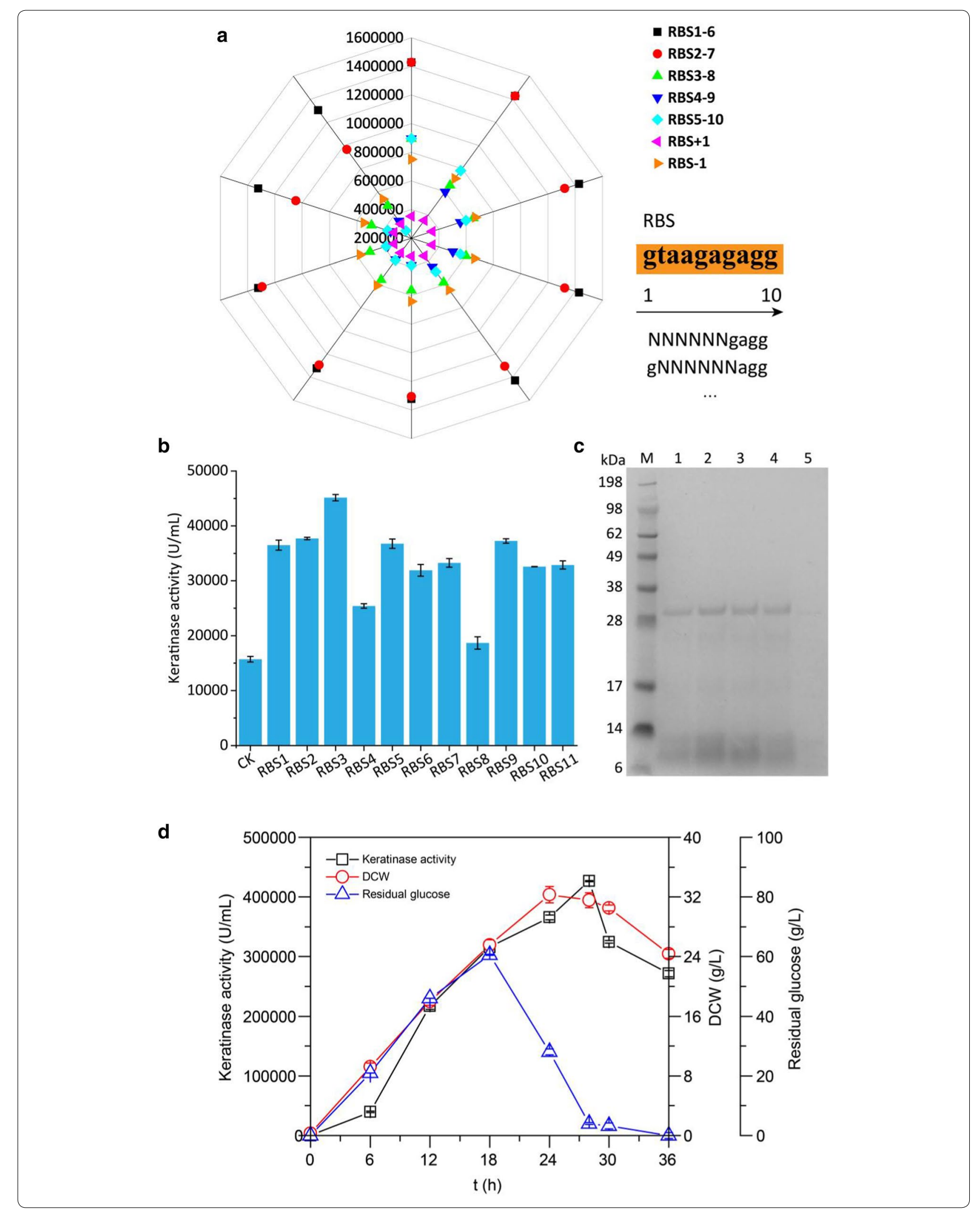


Table 1 Sequence, translation initiation rate, and $\Delta G_{\text {tot }}$ of the RBS mutants

\begin{tabular}{llcl}
\hline Name & $\begin{array}{l}\text { RBS mutant } \\
\text { sequence }\left(\mathbf{5}^{\prime} \rightarrow \mathbf{3}^{\prime}\right)\end{array}$ & $\begin{array}{l}\text { Translation } \\
\text { initiation rate } \\
\text { (a.u.) }\end{array}$ & $\boldsymbol{\Delta G}_{\text {total }}$ (kcal/mol) \\
\hline WT & GTAAGAGAGG & $136,321.8$ & -4.15 \\
RBS1 & GAGGGGGAGG & $1,323,117.0$ & -15.51 \\
RBS2 & GAATGGGAGG & $261,800.7$ & -11.91 \\
RBS3 & GAGAAGGAGG & $1,293,676.2$ & -15.45 \\
RBS4 & GAGGAGGAGG & $1,305,372.8$ & -15.47 \\
RBS5 & GTAAGAGAGG & $136,321.8$ & -10.45 \\
RBS6 & GGAGGGGAGG & $965,565.5$ & -14.80 \\
RBS7 & GTAAGAGAGG & $136,321.8$ & -10.45 \\
RBS8 & GGGGGGGAG & $1,323,117.0$ & -15.51 \\
RBS9 & GGATAGGAGG & $667,591.9$ & -13.98 \\
RBS10 & GGGAGGGAGG & $866,709.0$ & -14.56 \\
RBS11 & GAAAGGTAGG & $237,121.7$ & -11.68 \\
\hline
\end{tabular}

$\mathrm{KU} / \mathrm{mL}$ and $15.24 \mathrm{KU} / \mathrm{mL} / \mathrm{h}$, respectively (Fig. 2d). Further, the keratinase activity of KerZ1 was 3552 times higher than that of wild-type keratinase and 128.1 times higher than that of the initial recombinant keratinase, which is the highest yield reported thus far. This high yield of keratinase also indicated the suitability of Bacillus subtilis as a host for KerZ1 production.

\section{Keratinase ability to hydrolyze feathers}

The process of microbial degradation of keratin involves three essential steps, namely denaturation, decomposition, and transamination [13, 36, 37]. Denaturation is critical, and involves opening the dense disulfide bond structure of keratin. This study assessed the efficiency of three reducing agents in vitro to help open the disulfide bond. $\beta$-Mercaptoethanol, sodium sulfite, and dithiothreitol (DTT) were added to the fermentation system of keratinase KerZ1 $(45.14 \mathrm{KU} / \mathrm{mL})$ to promote feather hydrolysis. Figure 3 a shows that $0.1 \%$ sodium sulfite or DTT combined with KerZ1 degraded the feathers into fragments and soluble products. However, neither the individual reducing agents alone nor the recombinant keratinase with a high enzyme activity degraded the feathers. Furthermore, the most apparent change that occurred following the individual actions of these compounds was the partial fading of the feathers, suggesting that denaturation, i.e., disulfide bond cleavage, is essential for the degradation of keratin. In addition, due to the high toxicity of DTT, sodium sulfite, which is environmentally friendly and safe, was chosen to degrade the feathers in synergy with KerZ1.
Figure 3b shows that KerZ1 $(426.60 \mathrm{KU} / \mathrm{mL})$ with high enzymatic activity degraded a large proportion of the feathers during incubation at $60{ }^{\circ} \mathrm{C}$ for $12 \mathrm{~h}$, leaving only the scapus. To define the optimal conditions for enzymatic hydrolysis, we first optimized the initial $\mathrm{pH}$ of the enzymatic hydrolysis system and the amount of sodium sulfite added. The results showed that an initial $\mathrm{pH}$ of 7 and addition of $1 \%$ sodium sulfite yielded the most effective result (Additional file 1: Figure S3). When KerZ1, which showed high enzyme activity, and $1 \%$ sodium sulfite were incubated with a feather for $4 \mathrm{~h}$, nearly the entire feather was hydrolyzed, leaving behind only a small amount of feather fragments. The solution in the hydrolysis system became clear as the reaction progressed toward $12 \mathrm{~h}$ (Fig. 3c). These results are novel in that it has not yet been reported, to our knowledge, that keratinase is capable of effectively hydrolyzing feathers so thoroughly in such a short time period $[38,39]$. These results reveal that a single keratinase with sufficiently high enzyme activity can hydrolyze feathers, and that the synergistic effect of sodium sulfite enhances the ability of keratinase to degrade feathers. Interestingly, the color of both systems gradually became lighter as the degradation process progressed, indicating the presence of active substances that induce fading in the hydrolysate [40].

Figure 4 demonstrates the change of state in the feathers after $4 \mathrm{~h}$ under different treatments as evaluated by scanning electron microscopy. When treated with $0.1 \%$ sodium sulfite alone, the plumes became fine but did not break. After treatment with KerZ1 and sodium sulfite, the feathers became deformed and fractured. In addition, treatment with low-activity KerZ1 alone did not significantly alter the structure of the feathers.

\section{Feather hydrolysate analysis}

Analysis of the types of amino acids as well as the content of the feather hydrolysate $(0.12 \mathrm{~g})$ generated via synergism of KerZ1 and 1\% sodium sulfite is shown in Table 2. Complete hydrolysis of the feathers resulted in amino acid production with a conversion rate of $49.3 \%$. Among them, the contents of glutamic acid, alanine, tyrosine, phenylalanine, leucine, and lysine were relatively high.

To maximize the conversion rate of the product, we optimized the amount and shape (feather or feather meal) of feathers, and the results show that when the amount of feathers was $100 \mathrm{~g} / \mathrm{L}$, the conversion rate of amino acids reached a maximum of $56.6 \%$ (Fig. 5a, b). Moreover, the wide variety of amino acids demonstrates the enormous potential of hydrolysates as feed protein additives (Fig. 5c). The hydrolysate also contains a mixed short peptide with a molecular weight of approximately $1.3 \mathrm{kDa}$ (Fig. 5e), and mass spectrometry results revealed 


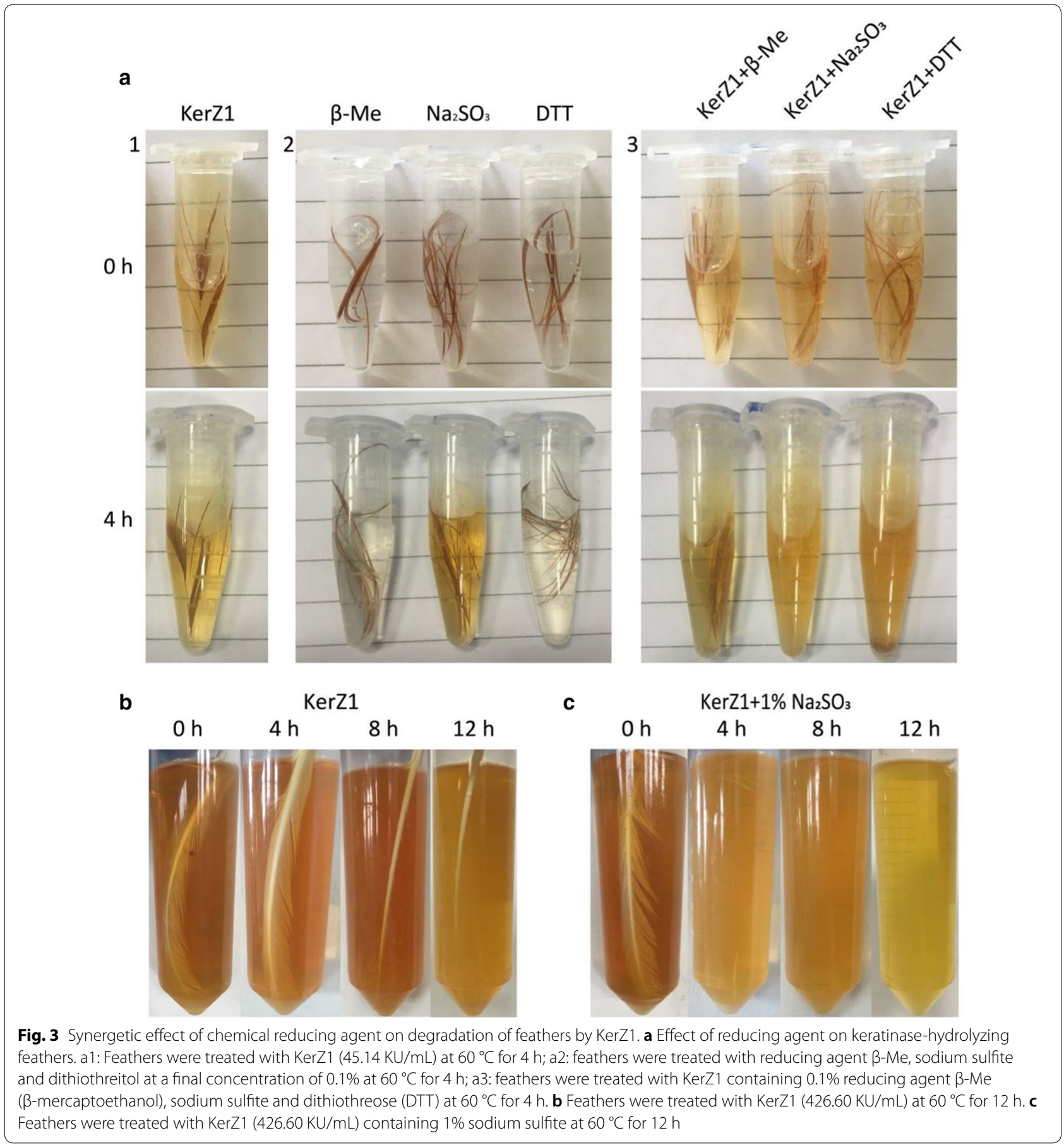

up to 12 active peptides that exhibited catalytic activity and antioxidant activity (Fig. 5d, f).

\section{Discussion}

The severe shortage of protein resources has motivated researchers to seek cheap and sustainable proteins, and to produce new functional materials in an environmentally friendly way. Keratin is a very valuable yet difficult-to-recycle fibrous protein that is a by-product of various meat- and poultry-processing operations $[1,41]$. Currently, identifying feed additives to replace expensive fishmeal requires acidic or alkaline hydrolysis to dissolve insoluble keratin and release amino acids [10, 42]. However, these methods do not address the issues 


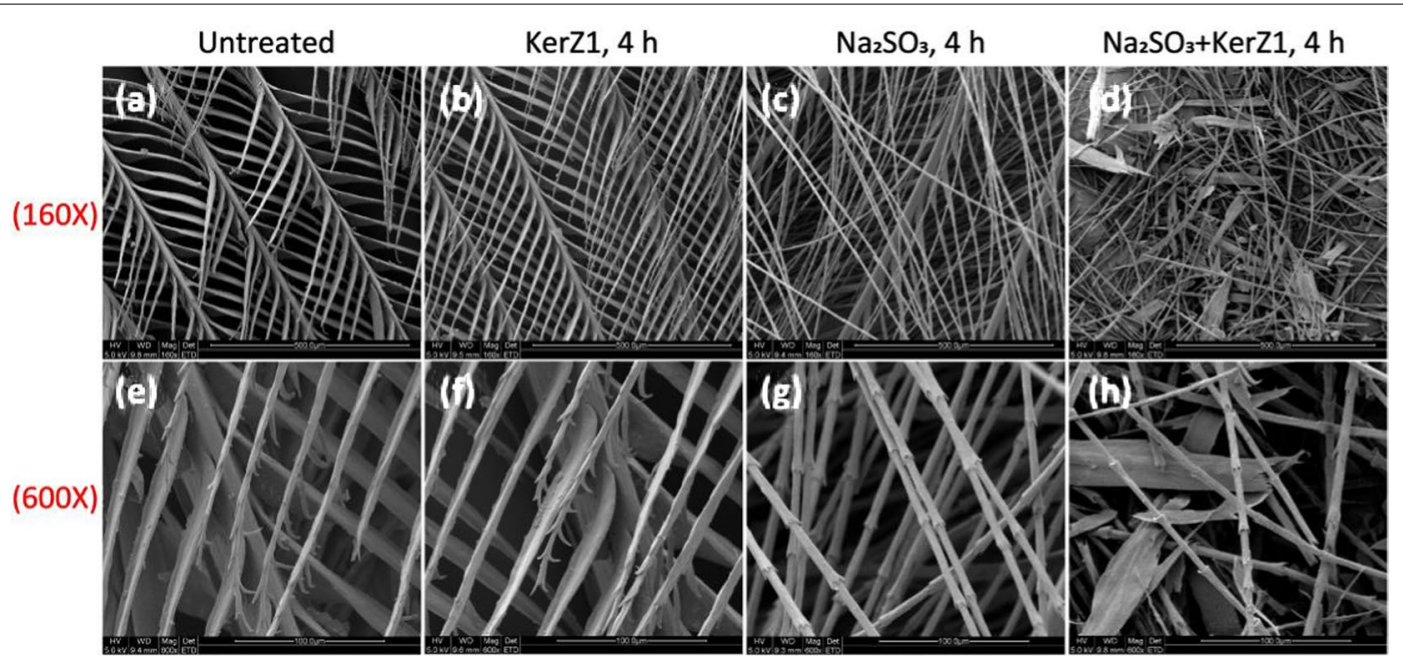

Fig. 4 Scanning electron microscopy images of feathers. a, e Untreated feathers. b, f Feathers were treated with $\mathrm{KerZ1}(45.14 \mathrm{KU} / \mathrm{mL})$ at $60{ }^{\circ} \mathrm{C}$ for 4 h. c, $\mathbf{g}$ Feathers were treated with $0.1 \%$ sodium sulfite at $60{ }^{\circ} \mathrm{C}$ for 4 h. $\mathbf{d}$, h F Feathers were treated with KerZ1 $(45.14 \mathrm{KU} / \mathrm{mL})$ containing $0.1 \%$ sodium sulfite at $60^{\circ} \mathrm{C}$ for $4 \mathrm{~h}$

Table 2 Amino acid content in feather hydrolysate

\begin{tabular}{lll}
\hline Amino acid & \multicolumn{2}{l}{ Concentration $(\mathbf{m g} / \mathbf{L})$} \\
\cline { 2 - 3 } & Supernatant & Hydrolysate \\
\hline asp & $27.93 \pm 1.57$ & $130.80 \pm 3.94$ \\
glu & $122.86 \pm 0.55$ & $380.78 \pm 15.42$ \\
ser & $7.72 \pm 0.89$ & $40.28 \pm 1.56$ \\
his & $6.38 \pm 1.21$ & $76.58 \pm 3.67$ \\
gly & $8.91 \pm 0.12$ & $94.30 \pm 6.19$ \\
thr & $25.70 \pm 2.44$ & $136.36 \pm 5.28$ \\
arg & $23.44 \pm 0.18$ & $19.80 \pm 0.31$ \\
ala & $138.23 \pm 4.36$ & $247.44 \pm 5.59$ \\
tyr & $55.57 \pm 1.38$ & $301.76 \pm 14.27$ \\
cys-s & $23.34 \pm 0.28$ & $28.58 \pm 0.59$ \\
val & $531.75 \pm 10.55$ & $337.62 \pm 16.20$ \\
met & $204.99 \pm 2.77$ & $247.16 \pm 4.63$ \\
phe & $401.76 \pm 8.54$ & $577.54 \pm 17.48$ \\
ile & $45.25 \pm 0.45$ & $105.62 \pm 7.19$ \\
leu & $50.30 \pm 2.11$ & $220.06 \pm 8.32$ \\
lys & $154.67 \pm 5.17$ & $360.48 \pm 14.29$ \\
Total & 1828.79 & 3305.16 \\
\hline
\end{tabular}

Supernatant means the fermentation supernatant; hydrolysate means the products from feather hydrolysis

surrounding the process complexity, energy investment, poor product absorption, and use of organic reagents [10, 43]. Hence, in the current study, we optimized the promoter, RBS, and fermentation conditions to obtain the most active keratinase to date via expression in Bacillus subtilis; this keratinase is capable of completely hydrolyzing feathers in a short period of time. In addition, the fermentation time required to achieve these results was shorter than those reported in previous studies, which is conducive to the industrialization of this enzyme.

In this study, although the optimum catalytic temperature of keratinase KerZ1 was determined to be $60^{\circ} \mathrm{C}$, its stability at this temperature was suboptimal, which led to the slow progress of keratin hydrolysis in the later stages. We attempted to use a lower temperature for enzymatic hydrolysis; however, this led to reduced hydrolysis efficiency and amino acid yield. Therefore, structural analysis based on the rational design of keratinase to enhance its thermal stability is necessary. Of note, similar effects can be achieved by increasing its catalytic efficiency and shortening the catalytic cycle as much as possible.

We also found that the activity of keratinase was positively correlated with the state of cell growth during fermentation and increased linearly within 6-24 h (Fig. 2d). This may be related to the characteristics of a constitutive promoter, with a superior cell growth state resulting in higher yields. Therefore, continued optimization of fermentation parameters and feeding strategies will have the opportunity to significantly reduce cell division time, thereby reducing the entire time required for a fermentation cycle.

Although this study achieved rapid degradation of feathers via keratinase, the catalytic mechanism employed by keratinase has not yet been characterized, accounting for one of the primary issues faced by keratinase researchers [44]. Similarly, an abundance of polypeptides is present in the hydrolysate; however, the specific functions of these peptides are unknown. However, the custom production of functional peptides 
a

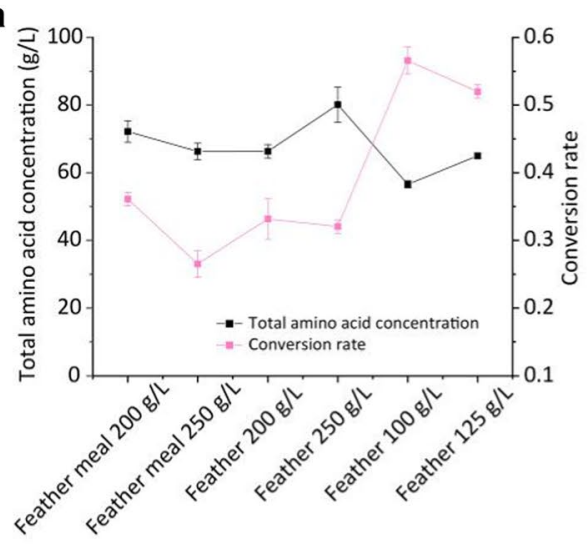

b

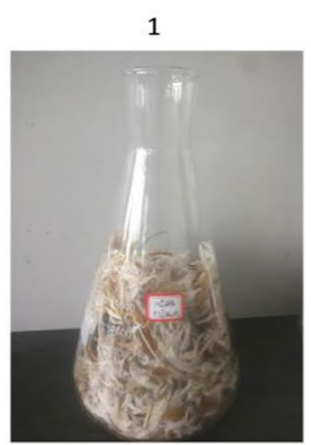

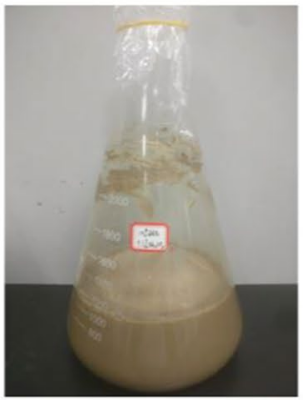

C

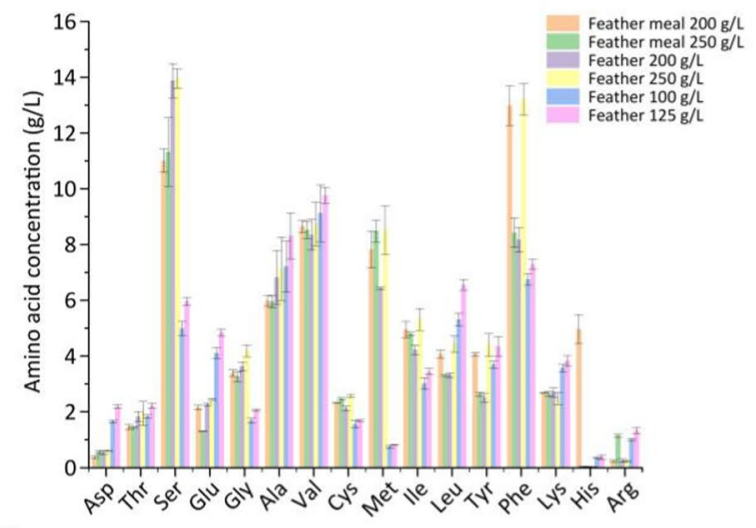

d
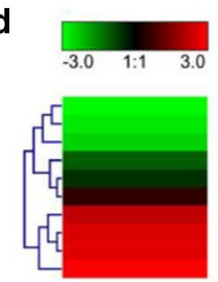

RVILPSPUVTLPGPIL IEPSPYVILPGPILS VIQPSPVUTLPGPILS DQPVEKLPFPIIA GDQPVEKLPFPII GDQPVEKLPFPI GDQPVEKLPFPIIA GDQPVEKLPFPIIA
GGGDIPRQPLYPPLPPRPG
DSRWVIQPSPWV
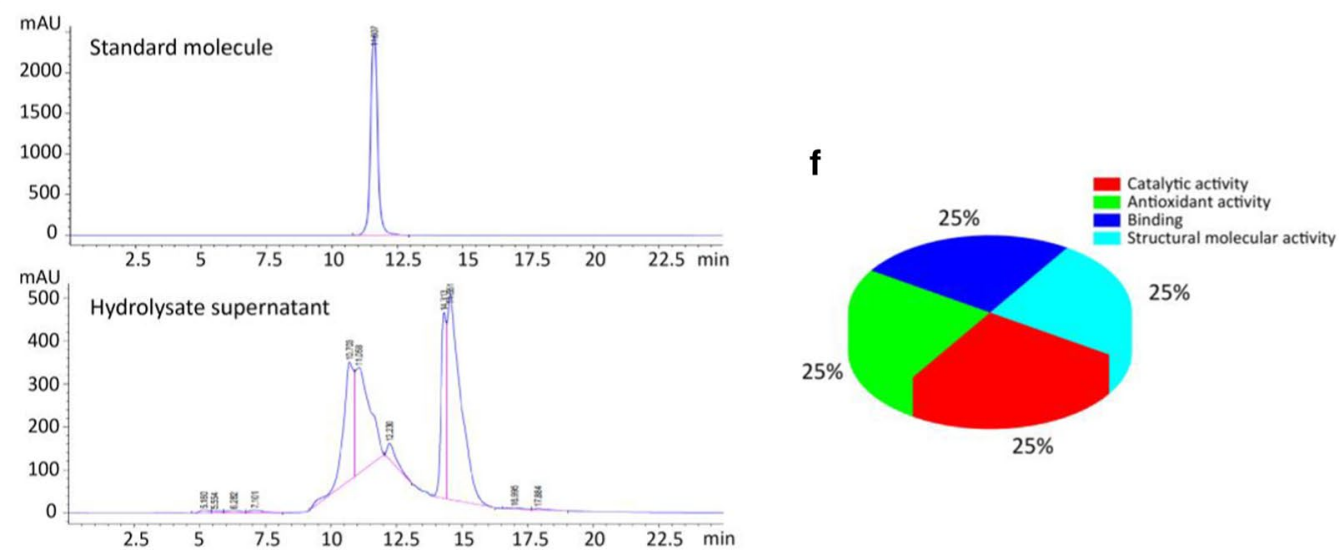

Fig. 5 Optimization of KerZ1-hydrolyzed feather system and analysis of hydrolysates. a Optimization of feather addition and feather morphology. b Feather shape display. 1:100 g untreated feather, 2:100 g feather treated with keratinase. c Contents of 16 common amino acids in hydrolysates obtained from different hydrolysis systems. d Types of peptides identified from hydrolysates obtained from a hydrolysis system containing $100 \mathrm{~g} / \mathrm{L}$ of feathers. e Molecular weight distribution of peptides in the hydrolysate obtained from a hydrolysis system containing $100 \mathrm{~g} / \mathrm{L}$ of feathers. $\mathbf{f}$ Possible biological functions corresponding to the peptides obtained from the database comparison

cannot be achieved by keratinase hydrolysis of feathers. Therefore, research on the substrate specificity and catalytic mechanism of keratinase will be of top priority for future studies.

\section{Conclusions}

This study efficiently expressed KerZ1 in B. subtilis WB600 by applying rational design at the transcriptional, translational, and fermentation levels allowing for the enzymatic activity of KerZ1 to reach $426.60 \mathrm{KU} / \mathrm{mL}$. We 
also propose a method for degrading feathers $(100 \mathrm{~g} / \mathrm{L})$ to produce amino acids based on the synergistic effect of high-activity KerZ1 and sodium sulfite, with the conversion rate reaching $56.6 \%$. In addition, this method is easy to use, quick, and does not generate toxic byproducts; it is also conducive to industrial scale-up production. In future studies, we plan to focus on the active peptides in feather hydrolysate, which will serve as a new, inexpensive source of functional peptides.

\section{Methods}

\section{Chemicals, strains, and plasmids}

All plasmid and promoter information has been added to Additional file 1: Table S1. Bacillus licheniformis BBE11-1 with keratinase secretion ability was screened by our group [45]. E. coli JM109 carrying the keratinase gene was constructed to amplify the recombinant plasmids (pMA5-ker, pP43NMK-ker, pSTOZ1622-ker, pHT43$k e r)$, and the recombinant plasmids were then transformed into Bacillus subtilis WB600; thus, the strains required for this study were successfully constructed. Amplification of gene fragments and linearized vectors using the PrimeSTAR Max Premix (from TaKaRa Bio Inc., Dalian, China) was followed by recombination of genes and vectors using the ClonExpress II One Step Cloning Kit (from Vazyme Biotech., Nanjing, China). All RBS sequences were optimized using the recombinant plasmid pP43NMK-ker as a template, and the linearized vector was religated using the Blunting Kination Ligation (BKL) Kit (from TaKaRa Bio Inc., Dalian, China).

\section{Medium and culture method}

LB medium ( $\mathrm{pH} 7.0)$ was used to activate seeds and contained $10 \mathrm{~g} / \mathrm{L}$ peptone, $5 \mathrm{~g} / \mathrm{L}$ yeast extract, and $10 \mathrm{~g} / \mathrm{L}$ $\mathrm{NaCl}$. The initial medium for fermentation had an initial $\mathrm{pH}$ of 7.2 and contained $10 \mathrm{~g} / \mathrm{L}$ tryptone, $10 \mathrm{~g} / \mathrm{L}$ glucose, $3 \mathrm{~g} / \mathrm{L} \mathrm{KH}_{2} \mathrm{PO}_{4}, 2 \mathrm{~g} / \mathrm{L} \mathrm{Na}_{2} \mathrm{HPO}_{4}$, and $0.6 \mathrm{~g} / \mathrm{L} \mathrm{MgSO}_{4}$. Optimized fermentation medium $(\mathrm{pH}$ 7.0) contained $10 \mathrm{~g} / \mathrm{L}$ yeast extract, $20 \mathrm{~g} / \mathrm{L}$ tryptone, $20 \mathrm{~g} / \mathrm{L}$ sucrose, $3 \mathrm{~g} / \mathrm{L} \mathrm{K \textrm {K } _ { 2 }} \mathrm{PO}_{4}, 6 \mathrm{~g} / \mathrm{L} \mathrm{Na}_{2} \mathrm{HPO}_{4}$, and $0.3 \mathrm{~g} / \mathrm{L} \mathrm{MgSO}_{4}$. The culture conditions of the shake flask were $37{ }^{\circ} \mathrm{C}$ and $220 \mathrm{rpm}$. The feathers used in this study were untreated ordinary feathers obtained from a poultry market. The enzymatic hydrolysis process involving the feathers was simple, only requiring the mixing of the fermentation supernatant, sodium sulfite, and untreated feathers, followed by incubation at $60^{\circ} \mathrm{C}$ to allow the reaction to proceed for $12 \mathrm{~h}$.

\section{General procedure of keratinase activity assay}

Keratinase activity was determined by the Folin-Ciocalteu method, as described previously with slight modifications [46]. The reaction system, containing $150 \mu \mathrm{L}$ of
$50 \mathrm{mM}$ Gly/NaOH buffer (pH 9.0), $100 \mu \mathrm{L}$ of $2.5 \%$ soluble keratin, and $50 \mu \mathrm{L}$ of a suitably diluted enzyme solution, was incubated at $50{ }^{\circ} \mathrm{C}$ for $20 \mathrm{~min}$. The reaction was terminated by adding $200 \mu \mathrm{L}$ of $4 \%$ trichloroacetic acid (TCA) and centrifugation at $8000 \mathrm{rpm}$ at room temperature for $3 \mathrm{~min}$. Then, $200 \mu \mathrm{L}$ of the supernatant was mixed with $1 \mathrm{~mL}$ of $4 \% \mathrm{Na}_{2} \mathrm{CO}_{3}$ and $200 \mu \mathrm{L}$ of FolinCiocalteu reagent at $50{ }^{\circ} \mathrm{C}$ for $10 \mathrm{~min}$. The absorbance at $660 \mathrm{~nm}$ was measured and the corresponding enzyme activity was obtained by tyrosine standard curve conversion. All experiments were repeated three times and the samples from the control group were mixed with trichloroacetic acid before adding enzyme solution. The remaining operations were the same as those in case of the samples in the experimental group. In this study, one unit of keratinase activity was defined as an absorbance value increase of 0.001 units per minute at $660 \mathrm{~nm}$.

\section{General procedure of batch fermentation in a $15-\mathrm{L}$ fermenter}

All lab-scale amplification experiments were performed in a 15-L automatic fermenter. The primary seed liquid was obtained by culturing glycerol bacteria or single colonies at $37^{\circ} \mathrm{C}$ and $220 \mathrm{rpm}$ for $15 \mathrm{~h}$. These samples were transferred to $400 \mathrm{~mL}$ of $\mathrm{LB}$ and the secondary seed solution was prepared by continuous culture for $4 \mathrm{~h}$ under the same conditions. The secondary seed liquid was inoculated at $5 \%$ into a $15-\mathrm{L}$ fermenter system containing 8.0 $\mathrm{L}$ of fermentation medium, and the fermentation process were conducted at $37^{\circ} \mathrm{C}, 500 \mathrm{rpm}$ agitation, and $2.0 \mathrm{vvm}$ air flow rate. Dissolved oxygen was controlled at approximately $30 \%$ during fermentation by adjusting the stirring speed and air flow rate.

\section{Analysis of amino acids and peptides}

Amino acids in the feather hydrolysate supernatants were detected with an amino acid analyzer (Hitachi L-8900, Tokyo, Japan). The sample was precipitated with $10 \%$ sulfosalicylic acid at a ratio of 1:1 for more than $4 \mathrm{~h}$, centrifuged at $12,000 \mathrm{~g}$ for $10 \mathrm{~min}$, and the supernatant was retained. The final sample was diluted to $0.1 \mathrm{mM}$ with $0.02 \mathrm{M}$ hydrochloric acid. Conversion rate of the amino acids was calculated as follows:

Amino acid conversion rate $(\%)=100 \times A / B$,

where $B$ is the dry weight of the feathers before decomposition and $A$ the total amino acid content in the hydrolysate.

Peptides were detected by high-performance liquid chromatography (Agilent 1260 series, Santa Clara, CA, USA) using a gel column (TSK gel G2000SWXL $7.8 \times 300 \mathrm{~mm}$ ) for separation of the peptides by molecular weight. The mobile phase was phosphate buffer, and 
the flow rate was $0.8 \mathrm{~mL} / \mathrm{min}$. The detector, wavelength, and column temperature were VWD, $214 \mathrm{~nm}$, and $25^{\circ} \mathrm{C}$, respectively. The type and function analysis of the peptide was performed by Wuhan Jinkairui Bioengineering Co., Ltd (Wuhan, China).

\section{Supplementary information}

Supplementary information accompanies this paper at https://doi. org/10.1186/s13068-020-01700-4.

Additional file 1. Additional table and figures.

\section{Acknowledgements}

This work was supported by the National Key Research and Development Program of China (2017YFB0308401), the 111 Project (111-2-06), the National First-class Discipline Program of Light Industry Technology and Engineering (LITE2018-08), the grant from Pioneer Innovative Research Team of Dezhou, and the Open Project of Key Laboratory of Industrial Biotechnology, Ministry of Education, Jiangnan University (KLIB-KF201706).

\section{Authors' contributions}

ZP performed most of the methodology design, experiments, and analyses described in this manuscript, as well as wrote most of the manuscript. XM performed the enzymatic activity assays. GD and JC contributed to the discussion, writing, and revision of the manuscript. JZ contributed to the methodology design, discussion, and suggestions during the work and revised the final versions of the manuscript. All authors read and approved the final manuscript.

\section{Funding}

Funding sources are listed in the "Acknowledgements".

\section{Availability of data and materials}

All data generated or analyzed during this study are included in this published article and its additional files.

\section{Ethics approval and consent to participate}

Not applicable.

\section{Consent for publication}

Not applicable.

\section{Competing interests}

The authors declare that they have no competing interests.

\section{Author details}

'School of Biotechnology, Jiangnan University, 1800 Lihu Road, Wuxi 214122, China. ${ }^{2}$ National Engineering Laboratory for Cereal Fermentation Technology, Jiangnan University, 1800 Lihu Road, Wuxi 214122, China. ${ }^{3}$ Key Laboratory of Industrial Biotechnology, Ministry of Education, Jiangnan University, 1800 Lihu Road, Wuxi 214122, China.

Received: 12 June 2019 Accepted: 24 March 2020

Published online: 01 April 2020

\section{References}

1. Wang B, Yang W, Mckittrick J, Meyers MA. Keratin: structure, mechanical properties, occurrence in biological organisms, and efforts at bioinspiration. Prog Mater Sci. 2016;76:229-318.

2. da Silva RR. Keratinases as an alternative method designed to solve keratin disposal on the environment: its relevance on agricultural and environmental chemistry. J Agric Food Chem. 2018;66:7219-21.

3. Meyers MA, Chen PY, Lin YM, Seki Y. Biological materials: structure and mechanical properties. Prog Mater Sci. 2008:53:1-206.
4. Coulombe PA, Omary MB. 'Hard' and 'soft' principles defining the structure, function and regulation of keratin intermediate filaments. Curr Opin Cell Biol. 2002;14:110-22.

5. Wang B, Sullivan TN. A review of terrestrial, aerial and aquatic keratins: the structure and mechanical properties of pangolin scales, feather shafts and baleen plates. J Mech Behav Biomed Mater. 2017;76:4-20.

6. Meyers MA, Chen PY. Structural biological materials: critical mechanicsmaterials connections. Science. 2013;339:773-9.

7. McKittrick J, Chen PY, Bodde SG, Yang W, Novitskaya EE, Meyers MA. The structure, functions, and mechanical properties of keratin. JOM. 2012;64:449-68.

8. Bray DJ, Walsh TR, Noro MG, Notman R. Complete structure of an epithelial keratin dimer: implications for intermediate filament assembly. PLoS ONE. 2015;10:e0132706.

9. Schrooyen PMM, Dijkstra PJ, Oberthür RC, Bantjes A, Feijen J. Stabilization of solutions of feather keratins by sodium dodecyl sulfate. J Colloid Interface Sci. 2001;240:30-9.

10. Coward-Kelly G, Chang VS, Agbogbo FK, Holtzapple MT. Lime treatment of keratinous materials for the generation of highly digestible animal feed: 1. Chicken feathers. Bioresour Technol. 2006;97:1337-43.

11. Brebu M, Spiridon I. Thermal degradation of keratin waste. J Anal Appl Pyrol. 2011;91:288-95.

12. Ramakrishna MR, Sathi KR, Ranjita YC, Bee H, Reddy G. Effective feather degradation and keratinase production by Bacillus pumilus GRK for its application as bio-detergent additive. Bioresour Technol. 2017;243:254-63.

13. Verma A, Singh H, Anwar S, Chattopadhyay A, Tiwari KK, Kaur S, Dhilon GS. Microbial keratinases: industrial enzymes with waste management potential. Crit Rev Biotechnol. 2016;37:476-91.

14. Fang Z, Zhang J, Liu B, Du G, Chen J. Biodegradation of wool waste and keratinase production in scale-up fermenter with different strategies by Stenotrophomonas maltophilia BBE11-1. Bioresour Technol. 2013;140:286-91.

15. Gupta R, Sharma R, Beg QK. Revisiting microbial keratinases: next generation proteases for sustainable biotechnology. Crit Rev Biotechnol. 2013;33:216-28.

16. Jaouadi NZ, Rekik H, Elhoul MB, Rahem FZ, Hila CG, Aicha HSB, Badis A, Toumi A, Bejar S, Jaouadi B. A novel keratinase from Bacillus tequilensis strain Q7 with promising potential for the leather bating process. Int J Biol Macromol. 2015;79:952-64.

17. Tork SE, Shahein YE, El-Hakim AE, Abdel-Aty AM, Aly MM. Production and characterization of thermostable metallo-keratinase from newly isolated Bacillus subtilis NRC 3. Int J Biol Macromol. 2013;55:169-75.

18. Yang L, Wang H, Lv Y, Bai Y, Luo H, Shi P, Huang H, Yao B. Construction of a rapid feather-degrading bacterium by overexpression of a highly efficient alkaline keratinase in its parent strain Bacillus amyloliquefaciens K11. J Agric Food Chem. 2016;64:78-84.

19. Kroutil W, Mang H, Edegger K, Faber K. Recent advances in the biocatalytic reduction of ketones and oxidation of alcohols. Curr Opin Chem Biol. 2004;8:120-6.

20. Hollmann F, Arends IWCE, Buehler K, Schallmey A, Bühler B. Enzymemediated oxidations for the chemist. Green Chem. 2011;13:226-65.

21. Bernal $C$, Rondriquez $K$, Martínez R. Integrating enzyme immobilization and protein engineering: an alternative path for the development of novel and improved industrial biocatalysts. Biotechnol Adv. 2018;36:1470-80

22. Verma A, Singh H, Anwar S, Chattopadhyay A, Tiwari KK, Kaur S, Dhilon GS. Microbial keratinases: industrial enzymes with waste management potential. Crit Rev Biotechnol. 2017;37:476-91.

23. Brandelli A. Bacterial keratinases: useful enzymes for bioprocessing agroindustrial wastes and beyond. Food Bioprocess Technol. 2008;1:105-16

24. Cai C, Zheng X. Medium optimization for keratinase production in hair substrate by a new Bacillus subtilis KD-N2 using response surface methodology. J Ind Microbiol Biotechnol. 2009;36:875-83.

25. Daroit DJ, Correa APF, Brandelli A. Production of keratinolytic proteases through bioconversion of feather meal by the Amazonian bacterium Bacillus sp. P45. Int Biodeterior Biodegrad. 2011;65:45-51.

26. Su C, Gong JS, Sun YX, Qin J, Zhai S, Li H, Li H, Lu ZM, Xu ZH, Shi $J S$. Combining pro-peptide engineering and multisite saturation 
mutagenesis to improve the catalytic potential of keratinase. ACS Synth Biol. 2019;8:425-33.

27. Peng Z, Mao X, Zhang J, Du G, Chen J. Effective biodegradation of chicken feather waste by co-cultivation of keratinase producing strains. Microb Cell Fact. 2019;18:84.

28. Kong HG, Choi KH, Heo KR, Lee KY, Lee HJ, Moon BJ, Lee S-W. Generation of a constitutive green fluorescent protein expression construct to mark biocontrol bacteria using p43 promoter from Bacillus subtilis. J Plant Pathol. 2009:25:136-41.

29. Zhang K, Su L, Duan X, Liu L, Wu J. High-level extracellular protein production in Bacillus subtilis using an optimized dual-promoter expression system. Microb Cell Fact. 2017;16:32.

30. Duan YX, Chen T, Chen X, Zhao XM. Overexpression of glucose-6-phosphate dehydrogenase enhances riboflavin production in Bacillus subtilis. Appl Microbiol Biotechnol. 2010;85:1907-14.

31. Nguyen HD, Phan TTP, Schumann W. Expression vectors for the rapid purification of recombinant proteins in Bacillus subtilis. Curr Microbiol. 2007:55:89-93.

32. Liu B, Zhang J, Gu L, Du G, Chen J, Liao X. Comparative analysis of bacterial expression systems for keratinase production. Appl Biochem Biotechnol. 2014;173:1222-35.

33. Andreeva I, Belardinelli R, Rodnina MV. Translation initiation in bacterial polysomes through ribosome loading on a standby site on a highly translated mRNA. Proc Natl Acad Sci USA. 2018;115:4411-6.

34. Guiziou S, Sauveplane V, Chang H-J, Clerte C, Declerck N, Jules M, Bonnet J. A part toolbox to tune genetic expression in Bacillus subtilis. Nucleic Acids Res. 2016:44:7495-508.

35. Farasat I, Kushwaha M, Collens J, Easterbrook M, Guido M, Salis HM. Efficient search, mapping, and optimization of multi-protein genetic systems in diverse bacteria. Mol Syst Biol. 2014;10:731.

36. Kunert J. Keratin decomposition by dermatophytes. II. Presence of s-sulfocysteine and cysteic acid in soluble decomposition products. J Basic Microb. 2010;16:97-105.

37. Peng Z, Zhang J, Du G, Chen J. Keratin waste recycling based on microbial degradation: mechanisms and prospects. ACS Sustain Chem Eng. 2019;7:9727-36.
38. Maciel JL, Werlang PO, Daroit DJ, Brandelli A. Characterization of proteinrich hydrolysates produced through microbial conversion of waste feathers. Waste Biomass Valori. 2017:8:1177-86.

39. Saarela M, Berlin M, Nygren H, Lahtinen P, Honkapaa K, Lantto R, Maukonen J. Characterization of feather-degrading bacterial populations from birds'nests - potential strains for biomass production for animal feed. Int Biodeterior Biodegrad. 2017;123:262-8.

40. Wan MY, Dong G, Yang BQ, Feng H. Identification and characterization of a novel antioxidant peptide from feather keratin hydrolysate. Biotechnol Lett. 2015;38:643-9.

41. Herrmann H, Aebi U. Intermediate filaments: molecular structure, assembly mechanism, and integration into functionally distinct intracellular scaffolds. Annu Rev Biochem. 2004;73:749-89.

42. Jie M, Raza W, Xu YC, Shen Q-R. Preparation and optimization of amino acid chelated micronutrient fertilizer by hydrolyzation of chicken waste feathers and the effects on growth of rice. J Plant Nutr. 2008;31:571-82.

43. Kornillowicz-Kowalska T, Bohacz J. Dynamics of growth and succession of bacterial and fungal communities during composting of feather waste. Bioresour Technol. 2010;101:1268-76.

44. Lange L, Huang Y, Busk PK. Microbial decomposition of keratin in nature - a new hypothesis of industrial relevance. Appl Microbiol Biotechnol. 2016;100:2083-96.

45. Liu L, Liu Y, Shin HD, Chen R, Li J, Du G, Chen J. Microbial production of glucosamine and $\mathrm{N}$-acetylglucosamine: advances and perspectives. Appl Microbiol Biotechnol. 2013;97:6149-58.

46. Fang Z, Zhang J, Liu B, Du G, Chen J. Biochemical characterization of three keratinolytic enzymes from Stenotrophomonas maltophilia BBE11-1 for biodegrading keratin wastes. Int Biodeterior Biodegrad. 2013;83:171.

\section{Publisher's Note}

Springer Nature remains neutral with regard to jurisdictional claims in published maps and institutional affiliations.
Ready to submit your research? Choose BMC and benefit from:

- fast, convenient online submission

- thorough peer review by experienced researchers in your field

- rapid publication on acceptance

- support for research data, including large and complex data types

- gold Open Access which fosters wider collaboration and increased citations

- maximum visibility for your research: over $100 \mathrm{M}$ website views per year

At BMC, research is always in progress.

Learn more biomedcentral.com/submissions 